\title{
Tremor on the same extremity after axillary brachial plexus block
}

\author{
Aksiller brakiyal pleksus bloğu sonrası aynı ekstremitede tremor
}

\section{(D) Hüseyin Ulaş PINAR}

To the Editor,

Tremor, is a rare condition especially after regional block. Herein, I want to present a patient who have tremors on the same extremity after brachial plexus block.

A 59-year-old female patient who had been on hemodialysis for 10 years due to chronic renal failure was taken to the operation room for brachiobasilic AV fistula formation on right arm.

The patient had hyperparathyroidism and hypertension. There was also a right jugular vein dialysis catheter in the patient. For this reason, it is planned to perform axillary block instead of infraclavicular or supraclavicular block. After routine monitoring and sedation with $2 \mathrm{mg}$ midazolam IV and $2 \mathrm{I} / \mathrm{min} \mathrm{O}_{2}$ insufflation, axillary block was performed with $20 \mathrm{~mL}$ $0.5 \%$ Bupivacaine $\mathrm{HCl}$ and $10 \mathrm{~mL} 2 \%$ Lidocaine $\mathrm{HCl}$ using US guided multiple injection technique following antiseptic cleansing and covering. After being adequate anesthesia at the 10th minute, it was checked with the pin prick test, the surgery was completed without any complication for 180 minutes.

After the patient was taken to the PACU, rough tremor movements developed on the operated extremity. During the tremors lasting about 2-3 minutes she was conscious, the patient stated that he did not voluntarily make these movements, and even said that she could not move the arm because the motor block continued. On the basis of this, a $2 \mathrm{mg}$ midazolam was given IV as this condition could be a focal seizure. The tremor stopped on the patient's arm and did not repeat throughout the follow-up. Following the patient, the block effect peaked at the end of 6 hours. Pathologic findings were not found in brain MRI and EEG due to central etiology study. The patient was discharged without any problems after 2 days.

This type of tremor has not been described before during motor block dissolution. In the literature review, Moorthy and Dil[ ${ }^{[1]}$ described tremor in forearm, starting with drug injection and continuing for 3 minutes during axillary block application with $1.5 \%$ mepivacaine, indicating that tremor was stopped by completion of drug injection. Similarly, during the axillary block application bupivacain/xylocaine mixture, Zeidan ${ }^{[2]}$ experienced a tremor lasting 3 minutes, suppressed with $3 \mathrm{mg}$ midazolam in the ipsilateral upper and lower extremities. The interesting thing in my case is that I do not encounter this situation at the end of the 3 hour operation at PACU. It is difficult to predict which mechanism plays a role in the development of this tremor. However, the fact that it is controlled by midazolam suggests a possible central mechanism or psychogenic factors. A neurotoxicity associated with drug in the nerve may have caused the excitability of facilitatory mechanisms. The tremor reduction by tactile stimulation, may support this argument.

\section{References}

1. Moorthy SS, Dill DW. Tremor of the forearm during performance of axillary brachial plexus block. Reg Anesth Pain Med 2004;29(5):510. [CrossRef]

2. Zeidan AM. Unilateral tremor of the upper and lower limb after an axillary brachial plexus block. Reg Anesth Pain Med 2005;30(3):308. [CrossRef]

Department of Anesthesiology and Reanimation, Baskent University Konya Application and Research Center, Konya, Turkey

Submitted (Başvuru tarihi) 18.11.2018 Accepted after revision (Düzeltme sonrası kabul tarihi) 17.01.2019 Available online date (Online yayımlanma tarihi) 09.07.2019

Correspondence: Dr. Hüseyin Ulaş Pınar. Başkent Üniversitesi Konya Uygulama ve Araştırma Merkezi, Konya, Turkey.

Phone: +90 - 505 - 5251992 e-mail: huseyinpinar2002@yahoo.com

(C) 2019 Turkish Society of Algology

(c) (7) (\$) 